\title{
Comparative Study of Gamma and Neutron Irradiation Effects on the Silicon Solar Cells Parameters
}

Dejan Nikolić

Professor

Brcko District Government Bosnia and Herzegovina

\section{Aleksandra Vasić-Milovanović \\ Professor \\ University of Belgrade Faculty of Mechanical Engineering}

Due to its wide application areas, solar cells are exposed, in their work environment, to different types of radiation (cosmic radiation in the upper layers of the atmosphere, military and civilian nuclear facilities). Moreover, the used nuclear fuel emits $\gamma$ photons and neutrons at the same time, so different types of radiation damage appeared in solar cells located in the vicinity of these fuels. These damage have been caused by both gamma and neutron radiation. That's why very extensive researches have been undertaken with the aim of developing semiconductor devices whose work will be reliable in terms of increased levels of radiation. From the technological point of view, it is important to determine changes, caused by radiation, in the parameters of the silicon solar cells that affect their work. The aim of this paper is to present the comparative study of gamma and neutron irradiation effects on the solar cells parameters.

Keywords: solar cells, radiation damage, solar cells parameters

\section{INTRODUCTION}

Possibilities for the application of solar systems based on photovoltaic conversion of solar energy are very wide, primarily because of their relatively low cost and very important fact that solar energy is most acceptable source of electrical energy from the environmental point of view. Solar cells, the basic elements for photovoltaic conversion of solar energy, are especially susceptible to high temperatures and radiation damage, primarily due to their large surface. Degradation of electrical and optical characteristics of the solar cells as photo detectors in the irradiation conditions is one of the most important limitating factors for their application. In recent papers the efficiency and properties of solar cells in terms of various irradiation conditions have been observed [1-3].

A solar cell is an electronic device which directly converts sunlight into electricity. Light shining on the solar cell produces both a current and a voltage to generate electric power. This process requires firstly, a material in which the absorption of light raises an electron to a higher energy state, and secondly, the movement of this higher energy electron from the solar cell into an external circuit. The electron then dissipates its energy in the external circuit and returns to the solar cell. A variety of materials and processes can potentially satisfy the requirements for photovoltaic energy conversion, but in practice nearly all photovoltaic energy conversion uses semiconductor materials in the form of a $p$ - $n$ junction [4].

The basic solar cell parameters are: $I-V$ curve, shortcircuit current $(I \mathrm{sc})$, open-circuit voltage $\left(V_{\mathrm{OC}}\right)$, fill factor

Received: January 2015, Accepted: June 2015

Correspondence to: Dejan Nikolic

Brcko District Government,

Bulevar Mira 1, 76100 Brčko, Bosnia and Herzegovina

E-mail: nikolcorp@gmail.com

doi:10.5937/fmet1601099N

(C) Faculty of Mechanical Engineering, Belgrade. All rights reserved
$(F F)$, efficiency $(\eta)$, series resistance $\left(R_{\mathrm{S}}\right)$ and shunt resistance $\left(R_{\mathrm{sh}}\right)$.

The short-circuit current depends on a number of factors, the area of the solar cell, the number of photons, the spectrum of the incident light, the optical properties etc. When comparing solar cells of the same material type, the most critical material parameter is the collection probability which depends chiefly on the diffusion length and surface passivation. In a cell with perfectly passivated surface and uniform generation, the equation for the short-circuit current can be approximated as:

$$
I_{S C}=q G\left(L_{n}+L_{p}\right)
$$

where $G$ is the generation rate, and $L_{\mathrm{n}}$ and $L_{\mathrm{p}}$ are the electron and hole diffusion lengths respectively. The equation (1) indicates that the short-circuit current depends strongly on the generation rate and the diffusion length [5].

The $V_{\mathrm{OC}}$ can be determined from the carrier concentration [6]:

$$
V_{O C}=\frac{k T}{q} \ln \left[\frac{\left(N_{A}+\Delta n\right) \Delta n}{n_{i}^{2}}\right]
$$

where $k T / q$ is the thermal voltage, $N_{\mathrm{A}}$ is the doping concentration, $\Delta n$ is the excess carrier concentration and $n_{\mathrm{i}}$ is the intrinsic carrier concentration.

The fill factor is a parameter which, in conjunction with $V_{\text {oc }}$ and $I_{\text {sc }}$, determines the maximum power from a solar cell. The $F F$ is defined as the ratio of the maximum power from the solar cell to the product of $V_{\mathrm{oc}}$ and $I_{\mathrm{sc}}$.

The most commonly used expression for the $F F$ can be determined empirically as [7]:

$$
F F=\frac{V_{O C}-\ln \left(V_{O C}+0.72\right)}{V_{O C}+1}
$$


The efficiency is the most commonly used parameter to compare the performance of one solar cell to another and is defined as the ratio of energy output from the solar cell to input energy from the sun. The efficiency of a solar cell is determined as the fraction of incident power which is converted to electricity and is defined as [8]:

$$
\eta=\frac{V_{O C} I_{S C} F F}{P_{i n}}
$$

where $\eta$ is the efficiency and $P_{\text {in }}$ is input power.

Series resistance in a solar cell has three causes: firstly, the movement of current through the emitter and base of the solar cell; secondly, the contact resistance between the metal contact and the silicon; and finally the resistance of the top and rear metal contacts. The main impact of series resistance is to reduce the fill factor, although excessively high values may also reduce the short-circuit current.

Significant power losses caused by the presence of a shunt resistance, $R_{\mathrm{sh}}$, are typically due to manufacturing defects, rather than poor solar cell design. Low shunt resistance causes power losses in solar cells by providing an alternate current path for the lightgenerated current. Such a diversion reduces the amount of current flowing through the solar cell junction and reduces the voltage from the solar cell [5].

Solar cells are especially susceptible to radiation damage, primarily due to their large surface. The lifetime of the solar cell is restricted by the degree of radiation damage that the cell receives. This is an important factor that affects the performance of the solar cell in practical applications. Negative influence of radiation on electrical characteristics of the semiconducting devices is a well known and thoroughly investigated fact, especially when working in hostile conditions [9, 10, 11]. Solar cells used in space are exposed to all kinds of radiation, both wave and particle. Their special design (surface to volume ratio) makes them susceptible to radiation damage, and improvement of electrical performance of such damaged cells is the aim of many experiments $[12,13]$.

Gamma ray (high energy photons) interacts with material and creates two effects, the first one is ionization through Photoelectric effect, Compton scattering or pair production (depending on the energy of incident radiation) and the second one is atomic displacement. This displacement creates additional atomic movement on its track that may result in a cluster of defects into the atomic lattice. If the energy of gamma ray is high enough (above several hundred $\mathrm{keV}$ ) the pair generation occurs. The energy spectrum of the energetic electrons is called "slowing spectrum". The energetic electron interacts with a lattice atom. As a result, the lattice atom is displaced from the lattice site. This is so called primary knock on atom (PKA) [14, 15]. Interstitial PKA, vacancy, and complex of them form a deep level in bandgap (so-called the generationrecombination centre). The recombination centres in bulk region cause the reduction of carrier life time. In addition the deep levels compensate the donor or acceptor levels resulting in the reduction of effective carrier concentration, carrier removal (CR) effect. It affects the depletion layer width by becoming wider [16].

Neutron, as relatively heavy and uncharged particle, does not possess the ability for direct ionization of materials. The basic mechanism of the neutron interaction with the environment is through the elastic collision with the atomic cores of that environment while interaction with the electrons is negligible. Collision of neutrons with atoms in the crystal lattice cause displacement of atoms from the lattice forming a pair of interstitial atom and vacancy called the Frenkel defect. Primary displaced atoms typically have enough energy to create secondary defects. These vacancies may combine with dopant and impurity atoms to form stable defects, which, in turn, may serve as recombination centers, decreasing carrier lifetime. The decrease in carrier lifetimes in doped semiconductor materials after neutron fluence exposure has been characterized as an abrupt decrease followed by a rapid short-term anneal (on the order of a few hours) and a long-term anneal (on the order of months), in which the carrier lifetime increases [17]. Axness et al. [18] show that the lattice damage and carrier lifetime degradation are spatially dependent.

The aim of this paper is to present the parallel picture of gamma and neutron irradiation effects on solar cells parameters in order to make comparative review of degradation of solar cell structure in both cases.

\section{EXPERIMENTAL PROCEDURE}

Experimental measurement in this paper was carried out on the commercially available monocrystalline silicon solar panels (maximum power voltage $4.0 \mathrm{~V}$, maximum power current $100.0 \mathrm{~mA}$, dimension: $70 * 65 * 3.2 \mathrm{~mm}$ ).

First group of solar panels was irradiated with $\mathrm{Co}^{60}$ gamma source with dose of $2000 \mathrm{~Gy}$, the energy of $1.25 \mathrm{MeV}$, and half-life time of 5.27 years (this energy is sufficient for the creation of electron-hole pairs). The dose rate was $100 \mathrm{~Gy} / \mathrm{h}$ at a distance of $150 \mathrm{~mm}$ away from the radioactive source. Irradiation was performed through glass in controlled environment. The dose rate was measured by electrometer UNIDOS with ionization chamber TW 30012-0172, produced by PTW, Germany. Measurement uncertainty of the system is less than $1.2 \%$. The components were irradiated in the air at a temperature of $21{ }^{\circ} \mathrm{C}$ and relative humidity of $40 \%$ to $70 \%$. Irradiation was performed in professional laboratory at the Department of Radiation and Environmental Protection of the Vinča Institute of Nuclear Sciences in Belgrade, Serbia.

Second group of solar panels have been exposed to neutron and gamma radiation from ${ }^{241} \mathrm{Am}-\mathrm{Be}$ source, which is housed in the SSDL (Secondary Standard Dosimetry Laboratory) Institute of Nuclear Sciences "Vinča", Belgrade. ${ }^{241} \mathrm{Am}-\mathrm{Be}$ source emits gamma photons of low energy ( $60 \mathrm{keV}$ and $14 \mathrm{keV})$, so that for the activity of $3.7 \times 10^{10} \mathrm{~Bq}$, calculated the photon equivalent dose rate is $\hat{H}_{\gamma}=12 \mathrm{mSv} / \mathrm{hr}$, and the photon absorbed dose rate is $\check{D}_{\gamma}=12 \mathrm{mGy} / \mathrm{hr}$ at a distance of $5 \mathrm{~cm}$ from the source. The intensity of the neutron emission from this source is $2.7 \times 10^{6}$ neutrons $\mathrm{s}^{-1}$, and the mean 
energy of the neutrons $E_{\text {nav }}=5.5 \mathrm{MeV}$. Based on measurements of the quality factor for this neutron spectrum $Q_{\mathrm{n}}=7$, calculated the neutron absorbed dose rate $\check{D}_{\mathrm{n}}=1.714 \mathrm{mGy} / \mathrm{hr}$ and the equivalent dose rate of neutrons $\hat{H}_{\mathrm{n}}=12 \mathrm{mSv} / \mathrm{hr}$. This means that at $5 \mathrm{~cm}$ distance from the ${ }^{241} \mathrm{Am}-\mathrm{Be}$ source with a total absorbed dose rate is $\check{D}_{\text {tot }}=13.714 \mathrm{mGy} / \mathrm{hr}$, while the total equivalent dose is $\hat{H}_{\text {tot }}=24 \mathrm{mSv} / \mathrm{hr}$. In this experiment, the semiconductor devices were placed at a distance of $5 \mathrm{~cm}$ from the ${ }^{241} \mathrm{Am}-\mathrm{Be}$ source, and the exposure period was $16.75 \mathrm{hr}$. In this interval, the material components received of the total absorbed dose in the amount of $D_{\text {tot }}=229.71 \mathrm{mGy}$, and respectively, the total equivalent dose $H_{\mathrm{tot}}=402 \mathrm{mSv}$. The components were irradiated in the air at a temperature of $21^{\circ} \mathrm{C}$ and relative humidity of $40 \%$ to $70 \%$.

Before the irradiation, immediately after the irradiation and one month after the irradiation, solar cell parameters (series and parallel resistance, open-circuit voltage, short-circuit current and fill factor) have been measured in highly controlled conditions at room temperature. During the measurement, the samples were removed from the experimental room after absorption of the anticipated dose of radiation.

The third measurement has been undertaken one month after the irradiation, in order to give enough time for sample recovery. For this reason, the changes occurring in the samples can be considered as a permanent. Standard measurement equipment was used for measurement. The professional digital multimeter AMPROBE 33XR was used for the current measurement. Combined measurement uncertainty for all measurements was less than $1.2 \%[19,20]$.

\section{RESULTS AND DISCUSSION}

The basic solar cell parameters before and after gamma and neutron irradiation are shown in Fig. 1. to 6.

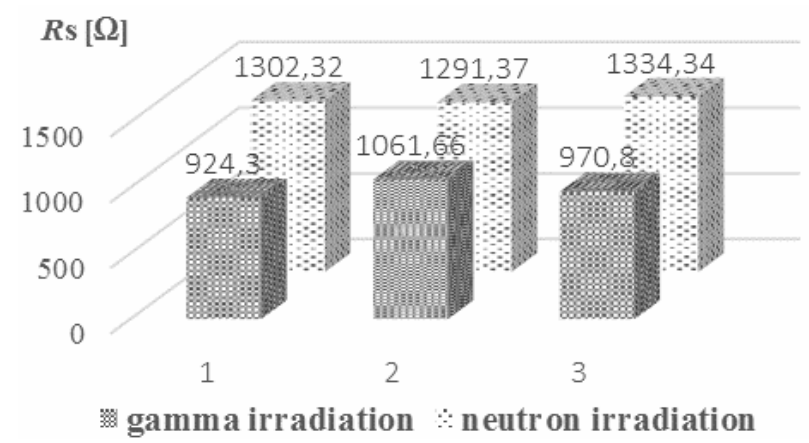

Figure 1. Series resistance (1-before the irradiation, 2immediately after the irradiation, 3-one month after the irradiation)

Both gamma and neutron radiation has the similar impact on solar cell parameters (Fig. 2 to 6) with the exception of series resistance. Neutron irradiation decreases the series resistance and gamma irradiation increases it (Fig. 1). High level of series resistance after gamma irradiation usually indicate the presence of impurity atoms and defects localized in the depletion region acting as traps for recombination or tunnelling effects, increasing dark current of the cell.
Zdravković et al. [21] show that the series resistance has been decreased for the higher neutron irradiation doses. It could be explained by the fact that during fabrication process of any semiconducting device, structural defects and impurities that were unavoidably made produce tension in the crystal lattice. Some irradiation doses could lead, similar to the annealing, to the relaxation of crystal structure and the decease of series resistance.

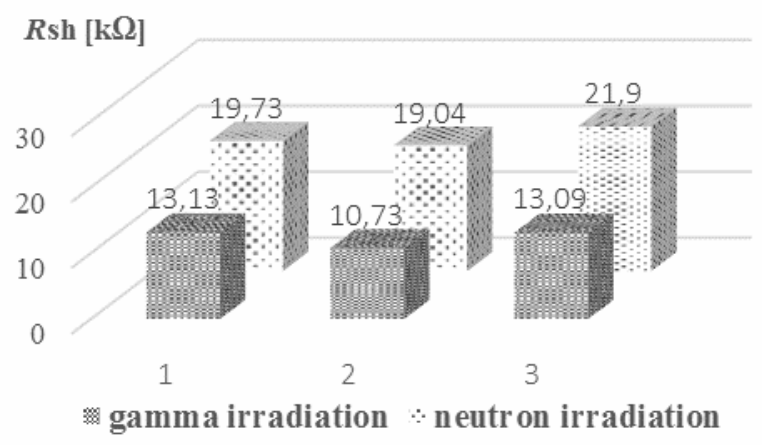

Figure 2. Shunt resistance (1-before the irradiation, 2immediately after the irradiation, 3-one month after the irradiation)

The decrease of shunt resistance indicates the presence of defects introduced by irradiation. Gamma radiation causes more significant displacement damage (defects) than neutron radiation so the reduction of shunt resistance is greater (Fig. 2).

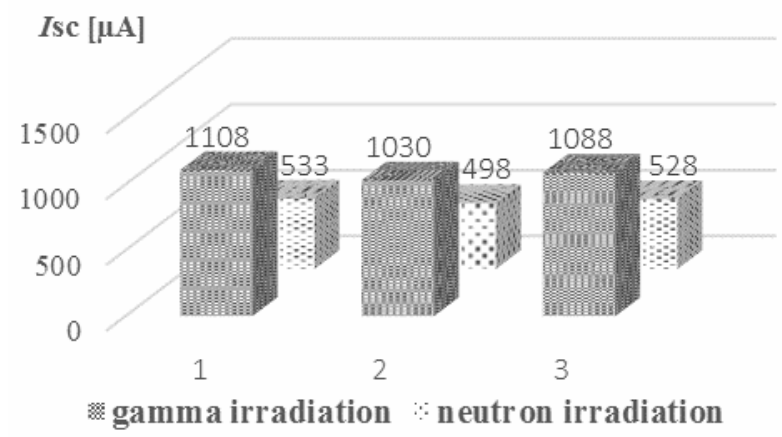

Figure 3. Short-circuit current (1-before the irradiation, 2immediately after the irradiation, 3-one month after the irradiation)

Short-circuit current strongly depends on the electron and hole diffusion lengths, refer to (1), so, since the gamma and neutron radiation reduces the diffusion length, the short-circuit current will also decrease (Fig. 3).

Radiation damage due to neutrons is, as mentioned above, primarily connected to the displacement of silicon atoms from their lattice sites in the crystalline silicon solar cells, leading to destruction and distortion of local lattice structure and formation of defects. If, under the influence of neutrons, stable defects are made, they could, together with impurity atoms, donors and for example implanted atoms, form complex defects acting as recombination sites or traps, significantly decreasing minority carrier lifetime. This lifetime decrease produces degradation of electrical parameters of the cell, such as series resistance (Rs), output current and finally efficiency $(\eta)$ [12], as it shown in Fig. 1, 3 and 6. 


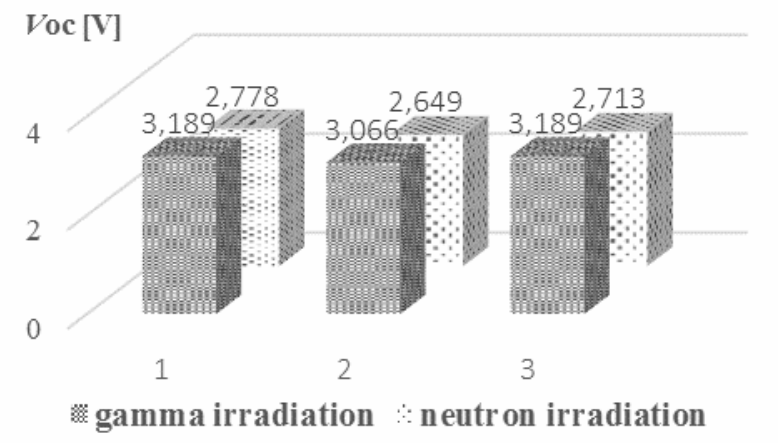

Figure 4. Open-circuit voltage (1-before the irradiation, 2immediately after the irradiation, 3-one month after the irradiation)

Tobnaghi et al. [22] observed a deterioration of the electric properties of solar cells under gamma irradiation when the gamma dose was increased ( 1 to 20 $\mathrm{kGy}$ ). It has been showed that, except the fill factor, which in some cases showed increased or relatively steady values, gamma radiation causes a significant reduction in the $I_{\mathrm{sc}}$ and $\eta$ while the $V_{\mathrm{oc}}$ is slightly reduced. Fig. 3, 4 and 6 show that at gamma dose of 2000Gy all of these parameters have a significant reduction.

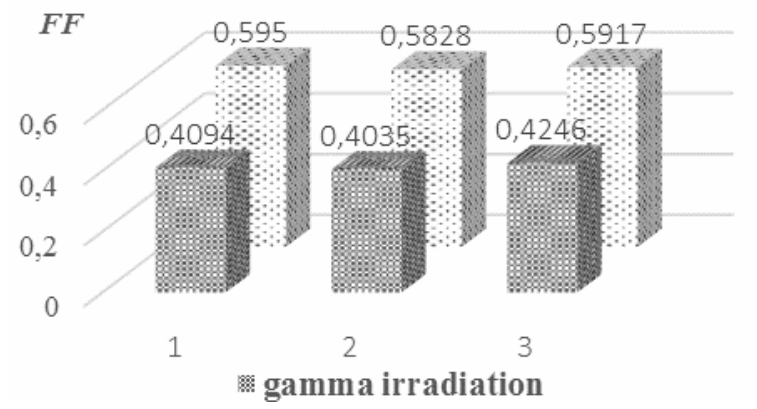

Figure 5. Fill factor (1-before the irradiation, 2-immediately after the irradiation, 3-one month after the irradiation)

The equation (3) indicates that with the decreasing of the open-circuit voltage, the fill factor will also decrease as it Fig. 4 and 5 show.

Output parameters of solar cell such as maximum output power, fill factor, efficiency, short circuit current and open circuit voltage strongly depend on internal parameters of solar cells such as series resistance. It has been proved that increasing of solar cell series resistance by the gamma radiation causes that the output parameters of solar cells decreased [23]. Fig. 3 to 6 confirm that.

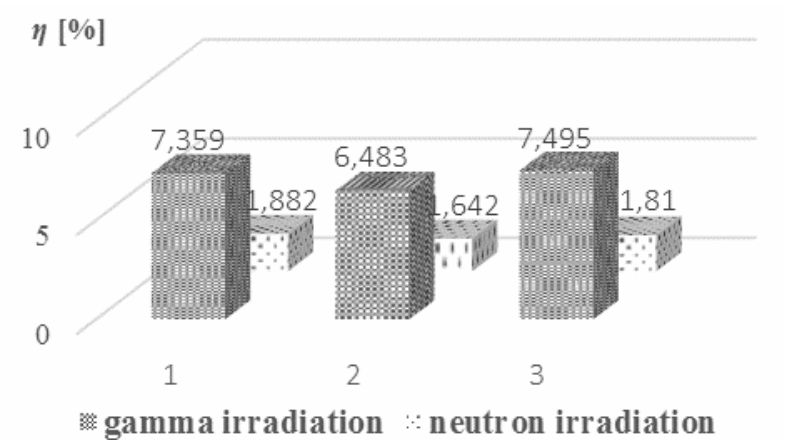

Figure 6. Efficiency (1-before the irradiation, 2-immediately after the irradiation, 3-one month after the irradiation)
Efficiency directly depends on $V_{\mathrm{OC}}, I_{\mathrm{SC}}$ and $F F$ (4). Decreasing all of these parameters causes significant reduction of solar cell efficiency (Fig. 6).

In the presence of both series and shunt resistances, the fill factor of the solar cell is given by [21]:

$$
\begin{aligned}
& F F=F F_{0}\left\{\left(1-1.1 R_{S}\right)+\frac{R_{S}^{2}}{5.4}\right\} . \\
& \cdot\left\{1-\frac{V_{O C}+0.7}{V_{O C}} \frac{F F_{0}}{R_{S h}}\left[\left(1-1.1 R_{S}\right)+\frac{R_{S}^{2}}{5.4}\right]\right\}
\end{aligned}
$$

where $F F_{0}$ is the fill factor which is not affected by the series and shunt resistance.

The equation (5) indicates impact of both series and shunt resistance on fill factor. According to (5), increasing of series resistance or/and decreasing of shunt resistance causes the decreasing of fill factor. Fig. 1,2 and 5 confirm it.

For this research, the long-term isothermal annealing at room temperature was used. The vacancies and interstitials are quite mobile in silicon at room temperature and hence, are referred to as unstable defects. After vacancy introduction by irradiation, vacancies move through the lattice and form more stable defects, such as divacancies and vacancy-impurity complexes. During the process of annealing, defects cluster and some electrical inactive defects become active in a cluster. When electrical properties are monitored during this defect rearrangement (or annealing) process, a decrease in the effectiveness of the damage with increasing time is typically observed $[25,26]$.

The effects of gamma radiation on the samples are slightly higher than those of neutron radiation. Probable cause is the radiation dose which is higher on gamma radiation.

\section{CONCLUSION}

Degradation of the main parameters of the solar cells and their improvement, as a consequence of annealing, was observed for all used samples. The results confirm that both gamma and neutron irradiation leads to degradation of solar cell parameters and then annealing improves it. Those parameters, in annealing process, were managed to recover to a value near the initial (the one before the irradiation). The combination of cells in the panel construction is a possible cause of this.

With the exception of series resistance, both gamma and neutron radiation has the similar impact on solar cell parameters. Neutron irradiation decreases the series resistance while gamma irradiation increases it.

\section{ACKNOWLEDGEMENT}

The Ministry of Education, Science and Techno-logical Development of Republic of Serbia supported this work under contracts 171007.

\section{REFERENCES}

[1] Vasić-Milovanović, A.: Increased temperature and radiation damage influence on solar cells characteristics, FME Transactions, Vol. 41, pp. 77-82, 2013. 
[2] Ali, K., Khan, S.A., MatJafri, M.Z.: ${ }^{60}$ Co $\gamma$ irradiation effects on electrical characteristics of monocrystalline silicon solar cell, International Journal of Electrochemical Science, Vol. 8, pp. 7831-7841, 2013.

[3] Tobnaghi, D.M., Madatov, R., Banki, T.: Effect of gamma radiation on the aged mono-crystalline silicon solar cells, Journal of Applied Science and Agriculture, Vol. 9, No. 3, pp. 903-907, 2014.

[4] Dimitrijev, S.: Understanding semiconductor devices, New York-Oxford, Oxford University Press, 2000.

[5] Lindholm, F.A., Fossum, J.G., Burgess, E.L.: Application of the superposition principle to solarcell analysis, IEEE Transactions on Electron Devices, Vol. 26, pp. 165-171, 1979.

[6] Sinton, R.A., Cuevus, A.: Contactless determination of current-voltage characteristics and minority-carrier lifetimes in semiconductors from quasi-steady-state photoconductance data, Applied Physics Letters, Vol. 69, pp. 2510-2512, 1996.

[7] Green, M.A.: Solar cell fill factors: General graph and empirical expressions, Solid-State Electronics, Vol. 24, pp. 788-789, 1981.

[8] McEvoy, A.J., Markvart, T., Castañer, L.: Practical Handbook of Photovoltaics: Fundamentals and Applications, Academic Press, 2012.

[9] Kovalyuk Z.D., Katerynchuk V.N., Politanska O.A., Sydor O.N., Khomyak V.V.: Effect of gamma radiation on the properties of InSe photodiodes, Technical Physics Utters, Vol. 3t, No. 5, pp. 359-360, 2005.

[10] Sporea D., Sporea A., Vata I.: Comparative study of gamma-ray and neutron irradiated laser diodes, International Conference on Applications of Photonic Technology, 2007, Ottawa ON, Canada, vol. 6796 (2), pp. 67962R.1-67962R.11.

[11] Alurralde M., Tahasi M.J.L., Bruno C.J., Martinez Bogado M.G., Pla J., Fernandez Vasquez J., Duran J., Shuff J., Burlon A.A., Stoliar P., Kreiner A.J.: Experimental and theoretical radiation damage studies on crystalline silicon solar cells, Solar Energy Materials \& Solar Cells, Vol. 82, pp. 531542, 2004.

[12] Vasić, A., Vujisić, M., Stanković, K., Jovanović, B.: Ambiguous Influence of Radiation Effects in Solar Cells, in: Progress In Electromagnetics Research Symposium Proceedings, 22-26.03.2010, Xi'an, China, pp. 1199-1203.

[13] Alexander, D.R.: Transient ionizing radiation effects in devices and circuits, IEEE Transaction on Nuclear Sciences, Vol. 50, No. 3, pp. 565-582, 2003.

[14] Holmes-Siedle, A., Adams, L.: Handbook of Radiation Effects, Oxford Science, 1993.

[15] Messenger, G.C., Ash, M.S.: The Effects of Radiation on Electronic Systems, Van Nostrand Reinhold, New York, NY, USA, $2^{\text {nd }}$ edition, 1991.
[16] Nikolić, D.S., Vasić, A.I., Lazarević, Đ.R., Obrenović, M.D.: Improvement possibilities of the $\mathrm{I}-\mathrm{V}$ characteristics of PIN photodiodes damaged by gamma irradiation, Nuclear Technology \& Radiation Protection, Vol. 28, No. 1, pp. 84-91, 2013.

[17] Srour, J.R., Marshall, C.J., Marshall, P.W.: Review of displacement damage effects in silicon devices, IEEE Transactions on Nuclear Science, Vol. 50, No. 3, pp. 653-670, 2003.

[18] Axness, C.L., Kerr, B., Keiter, E.R.: Analytic 1-D pn junction diode photocurrent solutions following ionizing radiation and including time-dependant changes in the carrier lifetime from a nonconcurrent neutron pulse, IEEE Transactions on Nuclear Science, Vol. 57, No. 6, pp. 3314-3321, 2010.

[19] Stanković, K., Vujisić, M., Kovačević, D., Osmokrović, P.: Statistical analysis of the characteristics of the some basic mass-produced passive electrical circuits used in measurement, Measurement, Vol. 44, No. 9, pp. 1713-1722, 2011.

[20] Vujisić, M., Stanković, K., Osmokrović, P.: A statistical analysis of measurement results obtained from nonlinear physical laws, Applied Mathematical Modeling, Vol. 35., No. 7, pp. 31283135, 2011.

[21]Zdravković, M., Vasić, A., Čavrić, B., Radosavljević, R., Stanković, K.: Radiation induced noise level in solar cells, in: PIERS Proceedings, 27-30.03.2012, Kuala Lumpur, Malaysia, pp. 11601164.

[22] Tobnaghi, D.M., Rahnamaei, A., Vajdi, M.: Experimental study of gamma radiation effects on the electrical characteristics of silicon solar cells, International Journal of Electrochemical Science, Vol. 9, pp. 2824-2831, 2014.

[23] Tobnaghi, D.M., Madatov, R., Mustafayev, Y., Abasov, F.: Influence of gamma radiation on electric properties of silicon solar cells, International Journal of Pure and Applied Sciences and Technology, Vol. 21, No. 1, pp 12$16,2014$.

[24] Green, M.A.: Solar cells-operating principles, technology and system application, Kensington, Australia: University of NSW, 1992.

[25] Simić, B., Nikolić, D., Stanković, K., Timotijević, Lj., Stanković, S.: Damage induced by neutron radiation on output characteristics of solar cells, photodiodes and phototransistors, International Journal of Photoenergy, Vol. 2013, Article ID 582819, 6 pages, 2013.

[26] Nikolić, D., Stanković, K., Timotijević, Lj., Rajović, Z., Vujisić, M.: Comparative study of gamma radiation effects on solar cells, photodiodes and phototransistors, International Journal of Photoenergy, Vol. 2013, Article ID 843174, 6 pages, 2013. 


\section{УПОРЕДНА СТУДИЈА ЕФЕКАТА ГАМА \\ И НЕУТРОНСКОГ ОЗРАЧИВАҢА НА \\ ПАРАМЕТРЕ СИЛИЦИЈУМСКИХ \\ СОЛАРНИХ ЋЕЛИЈА}

\section{Дејан Николић, Александра Васић- Миловановић}

Због широког подручја примене, соларне ћелије су, у свом радном окружењу, изложене различитим врстама зрачења (космичко зрачење у горњим слојевима атмосфере, војна и цивилна нуклеарна постројења). Штавише, коришћено нуклеарно гори- во у исто време емитује и $\gamma$ фотоне и неутроне тако да се у соларним ћелијама смештеним у близини ових горива јављају различите врсте радијационих оштећења. Ова оштећења су узрокована и гама и неутронским зрачењем. Због тога су предузимана врло опсежна истраживања са циљем развоја полупроводничких уређаја чији рад ће бити поуздан и у условима повећаног нивоа зрачења. Са технолошког аспекта, важно је утврдити промене, узроковане зрачењем, у параметрима соларних ћелија које утичу на њихов рад. Циљ овог рада је да се представи упоредна студија ефеката гама и неутронског озрачивања на параметре соларних ћелија. 